\title{
Comparative study of dendritic cells matured by using IL-1 $\beta$, IL-6, TNF- $\alpha$ and prostaglandins E2 for different time span
}

\author{
XUEJIE WU $^{1}$, FENG XU ${ }^{1}$, JINLIANG LIU ${ }^{1}$ and GUIQIANG WANG ${ }^{2}$ \\ ${ }^{1}$ Department of Infectious Diseases, Second Affiliated Hospital, Zhejiang University School of Medicine, Hangzhou, \\ Zhejiang 310009; ${ }^{2}$ Department of Infectious Diseases, Peking University First Hospital, Beijing 100034, P.R. China
}

Received May 27, 2016; Accepted April 11, 2017

DOI: 10.3892/etm.2017.4649

\begin{abstract}
Interleukin (IL)-1 $\beta$, IL-6, tumor necrosis factor (TNF)- $\alpha$ and prostaglandins E2 is considered as the standard cocktail for maturing dendritic cells (DCs). However, the appropriate time span for DC maturation with the standard cocktail remains unclear. The present study aimed to compare the differences between DCs matured with the standard cocktail for 24 and $48 \mathrm{~h}$, respectively, and determine whether 24-h stimulation was sufficient for DC maturation. The findings demonstrated that, compared with DCs matured for $48 \mathrm{~h}$, the levels of cluster of differentiation (CD)80, CD83, CD86 and programmed death-ligand 1 expression in DCs matured for $24 \mathrm{~h}$ were relatively lower. However, with the exception of CD80 whose mean fluorescence intensity (MFI) was higher in DCs matured for $48 \mathrm{~h}$, the MFI values of other surface markers were comparable. Notably, the MFI of CD40 was higher in DCs matured for $24 \mathrm{~h}$. In addition, the viability, $\mathrm{T}$ cell stimulatory capacity in allogeneic mixed lymphocyte reaction and cytokine production, including IL-12p40, IL-12p70 and IL-10, were all comparable between DCs matured for 24 and $48 \mathrm{~h}$, respectively. These results indicated that $24-\mathrm{h}$ stimulation may be sufficient for DC maturation when using the standard cocktail.
\end{abstract}

Correspondence to: Dr Xuejie Wu, Department of Infectious Diseases, Second Affiliated Hospital, Zhejiang University School of Medicine, 88 Jiefang Road, Hangzhou, Zhejiang 310009, P.R. China E-mail:wuxuejie81@163.com

Professor Guiqiang Wang, Department of Infectious Diseases, Peking University First Hospital, 8 Xishiku Street, Beijing 100034, P.R. China

E-mail: john131212@yahoo.com.cn

Abbreviations: DCs, dendritic cells; PBMCs, peripheral blood mononuclear cells; GM-CSF, granulocyte-macrophage colony-stimulating factor; PGE2, prostaglandin E2; PD-L1, programmed cell death ligand 1

Key words: dendritic cells, monocytes, cytokines, immunotherapy

\section{Introduction}

Dendritic cells (DCs) are the most potent antigen-presenting cells and they have a critical role in innate and adaptive immunity $(1,2)$. Notably, they have a unique ability to initiate naive $\mathrm{T}$ cells (3). Immature DCs (imDC), which are located in peripheral tissues (such as the skin, capture and process antigens), migrate to the draining lymphoid organs where they are able to prime cluster of differentiation (CD) $4+$ and CD8+ $\mathrm{T}$ cells (4). However, whether they induce $\mathrm{T}$ cell-mediated immune response or tolerance is determined by the status of DCs (5).

Over the past few years, great interest has been focused on the development of DC-based immunotherapy due to the unique capacity of DCs to initiate naive T cells. It is now straight-forward to generate monocyte-derived DCs (moDCs) in vitro using granulocyte-macrophage colony-stimulating factor (GM-CSF) and IL-4 (6,7). A number of protocols have been tested for their capacity to induce DC maturation (8-11) due to the fact that fully mature DCs are more powerful than $\mathrm{imDC}$ at inducing immune responses (5). Among these protocols, IL-1 $\beta$, IL-6, TNF- $\alpha$ and prostaglandins E2 (PGE2), which was developed by Jonuleit et al (8), has become the gold standard cocktail for DC maturation. To date, DCs matured with this standard cocktail have been applied in the treatment of patients with different malignant tumors and promising results have been demonstrated in several clinical studies (12-16).

Although this standard cocktail has been widely used, the appropriate time span for DC maturation has not been determined. It has been reported that DCs gradually lose their function over a few days after maturation (17). Therefore, shortening the time to mature DCs in vitro may be beneficial for the effectiveness of DC-based therapeutic vaccine in vivo. Therefore, the present study comprehensively compared DCs matured for 24 and $48 \mathrm{~h}$ using the standard cocktail to determine the appropriate time span for DC maturation.

\section{Materials and methods}

Isolation of PBMCs and positive selection of CD14+ monocytes. Peripheral blood mononuclear cells (PBMCs) were isolated by Ficoll-Paque Plus (GE Healthcare, Chicago, IL, USA) density gradient centrifugation from healthy human heparinized blood (Beijing 307 Hospital of Chinese People's Liberation Army, 
Beijing, China). All subjects were recruited in August 2015 $(\mathrm{n}=3$; male: Female, $1: 2$; age $27.33 \pm 1.53$ years). Inclusion criteria for subjects in this study were i) no fever; ii) normal renal and hepatic function; iii) no drug use within one month. Exclusion criteria were i) infection with hepatitis B virus, hepatitis $C$ virus, hepatitis D virus or human immunodeficiency virus; ii) liver cirrhosis or hepatocellular carcinoma, fatty liver or alcoholic hepatitis. PBMCs were washed by PBS twice before CD14+ monocytes isolation using human CD14+ microbeads (Miltenyi Biotec GmbH, Bergisch Gladbach, Germany) according to the manufacturer's instructions. The purity of the isolated CD14+ monocytes was $>90 \%$. The Ethics Committee at the Second Affiliated Hospital, Zhejiang University School of Medicine (Hangzhou, China) approved this study. Informed consent was obtained from all participants.

DCs generation. Monocyte-derived DCs were generated as previously described with minor modifications (9). CD14+ monocytes were re-suspended in serum-free AIM-V medium (Gibco; Thermo Fisher Scientific, Inc., Waltham, MA, USA) supplemented with $100 \mathrm{U} / \mathrm{ml}$ penicillin and $100 \mu \mathrm{g} / \mathrm{ml}$ streptomycin and placed in 24-well plates (Corning, Inc., Corning, $\mathrm{NY}$, USA) for incubation at $37^{\circ} \mathrm{C}$ in a humidified atmosphere containing $5 \% \mathrm{CO}_{2}$ for $2 \mathrm{~h}$. Following complete aspiration of the supernatant, fresh AIM-V medium supplemented with GM-CSF (1,000 IU/ml) and IL-4 (500 IU/ml; both PeproTech, Inc., Rocky Hill, NJ, USA) was added to the cells. The cells were supplied every 2 days with fresh medium. On day 5 , imDC were harvested and cultured in the presence of IL-1 $\beta$, IL-6, TNF- $\alpha$ (1,000 IU/ml; PeproTech, Inc.) and PGE2 $(1 \mu \mathrm{g} / \mathrm{ml}$; Sigma-Aldrich; Merck KGaA, Darmstadt, Germany) for a further 24 or $48 \mathrm{~h}$, respectively, to obtain mature DCs $(\mathrm{mDC})$. Supernatants were collected and retained for cytokine analysis.

Flow cytometric analysis. Flow cytometry was performed using FACS Calibur (BD Biosciences). Cells were stained with the following monoclonal antibodies: Fluorescein isothiocyanate (FITC)-labeled antibodies against CD40 and CD86, phycoerythrin (PE)-labeled antibodies against CD80, CD83 and programmed death-ligand 1 (PD-L1), peridinin chlorophyll protein (PerCP)-labeled antibodies against human leukocyte antigen-D related (HLA-DR), allophycocyanin-labeled antibodies against CD14, CD11c, and isotype matched control antibodies (BD Biosciences). FACS data were analyzed using FlowJo software (version 5.7.2; Tree Star, Inc.).

Apoptosis assay. Freshly harvested $\mathrm{mDC}\left(1 \times 10^{5}\right)$ were washed twice with cold PBS and incubated with Annexin-V-PE and 7-amino-actinomycin D (7-AAD) for $15 \mathrm{~min}$ before fluorescence-activated cell sorting (FACS) analysis. FACS data were analyzed using FlowJo software (version 5.7.2; Tree Star, Inc., Ashland, OR, USA).

Endocytic ability during the maturation of DCs. ImDC and $\mathrm{mDC}\left(1 \times 10^{5}\right)$ cells were suspended in $100 \mu 1$ of AIM-V and incubated with FITC-dextran $(1 \mathrm{mg} / \mathrm{ml})$ for $60 \mathrm{~min}$ either at $37^{\circ} \mathrm{C}$ or $4^{\circ} \mathrm{C}$ (negative control). Afterwards, cells were washed three times in cold PBS prior to FACS analysis. FACS data were analyzed using FlowJo software (version 5.7.2).
Allogeneic mixed lymphocyte reaction (MLR). $\mathrm{mDC}$ matured for 24 or $48 \mathrm{~h}$ were treated with $50 \mu \mathrm{g} / \mathrm{ml}$ mitomycin-C at $37^{\circ} \mathrm{C}$ in a humidified $5 \% \mathrm{CO}_{2}$ atmosphere for $45 \mathrm{~min}$. Afterwards, DCs were washed three times and added to allogeneic CD14+ monocytes depleted PBMCs $\left(10^{5}\right.$ cells) at a ratio 1:10 (DCs:PBMCs) in 96-well plates (Corning, Inc.) for 4 days, then $20 \mu 1$ CellTiter 96 Aqueous non-radioactive reagent (Promega Corp., Madison, WI, USA) was added to each well and cultures were continued for another $4 \mathrm{~h}$. Following this, absorbance at $490 \mathrm{~nm}$ was recorded using an ELISA plate reader.

Cytokines secretion analysis. Production of IL-12p40, IL-12p70 and IL-10 was assayed by ELISA kit (BioLegend, Inc., San Diego, CA, USA) according to the manufacturer's instructions.

Statistical analysis. Comparisons between groups of quantitative variables were performed using the Mann-Whitney U test. The test was two-sided and differences were considered significant if $\mathrm{P}<0.05$. Data handling and analysis were performed with SPSS software for Windows, version 13.0 (SPSS Inc., Chicago, IL, USA).

\section{Results}

Purity of CD14+ monocytes and mature DCs. In order to improve the purity of monocyte-derived DCs, we first selected the CD14+ monocytes from PBMCs by using human CD14+ microbeads instead of the conventional cell adherent technique. Our data showed that the proportion of CD14+ monocytes in PBMCs was approximately $6.79 \%$ prior to selection. However, this number increased to $91.98 \%$ following selection (Fig. 1A). The purity of DCs matured for 24 and $48 \mathrm{~h}$ was 90.22 and $92.95 \%$, respectively, of which the majority of mature DCs were CD11c+ DCs (Fig. 1B).

Phenotypic characteristics of mature DCs. In the present study, co-stimulatory and co-inhibitory surface markers, including CD40, CD80, CD83, CD86, HLA-DR and PD-L1, were compared between DCs matured via a standard cocktail for 24 and $48 \mathrm{~h}$ by flow cytometry. Compared to DCs matured for $24 \mathrm{~h}, \mathrm{DCs}$ matured for $48 \mathrm{~h}$ expressed higher levels of CD80, both in frequency and mean fluorescence intensity (MFI). For CD83 and CD86 exhibited higher levels of frequency when matured for $48 \mathrm{~h}$ instead of $24 \mathrm{~h}$, however no differences were found in MFI. Notably, similar expression levels of CD40 were found in frequency after $48 \mathrm{~h}$, whereas MFI was higher in DCs matured for $24 \mathrm{~h}$. No differences of HLA-DR were found in terms of frequency and MFI. However, for the inhibitory molecule, PD-L1, a higher frequency was also observed in DCs matured for $48 \mathrm{~h}$. The frequencies of co-stimulatory molecules for both DCs all exceeded $90 \%$, with the exception of CD83 (Table I).

Viability and endocytosis of mature DCs. High viability is important for the preparation of effective DC-based therapeutic vaccines. Therefore, we determined and compared the viability of DCs matured via the standard cocktail for different time spans. Our data showed that the viability of DCs matured for 24 and $48 \mathrm{~h}$, respectively, were similarly 
Table I. Phenotypic characteristics of mature DCs.

\begin{tabular}{lcrc}
\hline & & \multicolumn{2}{c}{ Mature DCs } \\
\cline { 3 - 4 } Markers & Value & $24 \mathrm{~h}$ & $48 \mathrm{~h}$ \\
\hline \multirow{2}{*}{ CD40 } & $\%$ & 92.24 & 96.57 \\
& MFI & 67.21 & $59.22^{\mathrm{a}}$ \\
CD80 & $\%$ & 93.94 & $98.82^{\mathrm{a}}$ \\
& MFI & 149.24 & $247.51^{\mathrm{a}}$ \\
CD83 & $\%$ & 83.55 & $94.98^{\mathrm{a}}$ \\
& MFI & 81.90 & 89.17 \\
CD86 & $\%$ & 94.47 & $99.52^{\mathrm{a}}$ \\
& MFI & 198.56 & 216.83 \\
PD-L1 & $\%$ & 95.03 & $98.01^{\mathrm{a}}$ \\
& MFI & 105.18 & 135.52 \\
HLA-DR & $\%$ & 97.22 & 99.57 \\
& MFI & 629.59 & 675.37 \\
\hline
\end{tabular}

Phenotypes of mature DCs were analyzed by flow cytometry. ${ }^{\mathrm{a}} \mathrm{P}<0.05$. MFI, mean fluorescence intensity; DCs, dendritic cells; CD, cluster of differentiation; PL-L1, programmed death-ligand 1; HLA-DR, human leukocyte antigen-D related.

high and exceeded $90 \%$ (Fig. 2A). It is known that the ability to take up antigens is one of the most important functions of immature DCs and this capacity decreases quickly upon maturation (18). Consistent with this, we found that imDCs showed high endocytosis while the endocytic capacity of DCs matured for 24 and $48 \mathrm{~h}$ both decreased rapidly to a similar extent (Fig. 2B).

T cell stimulatory capacity and cytokine productions of mature DCs. The T cell stimulatory capacity of DCs matured for different time spans was assessed via an allogeneic mixed lymphocyte reaction. Our data showed that the T cell stimulatory capacity of DCs matured for 24 and 48 h, respectively, was comparable (Fig. 3). We subsequently detected the cytokine production of $\mathrm{mDCs}$ from both time points and found that mDCs matured for 24 and $48 \mathrm{~h}$, respectively, secreted comparable high levels of IL-12p40, which is a subunit of IL-12p70. Both groups of cells secreted comparable low levels of IL-10; however, mDCs matured for $24 \mathrm{~h}$ secreted relatively lower levels of bioactive IL-12p70 (Fig. 4).

\section{Discussion}

IL-1 $\beta$, IL-6, TNF- $\alpha$ and PGE2 has been widely used as a standard cocktail for in vitro generation of mature DCs $(8,12-16,19,20)$. However, the optimal time for DC maturation using this standard cocktail has not been established. In the present study, we found that DCs matured for $24 \mathrm{~h}$ were, phenotypically speaking, also fully mature compared to DCs matured for $48 \mathrm{~h}$. DCs matured for $24 \mathrm{~h}$ expressed even higher levels of the CD40 co-stimulatory molecule in terms of MFI, whereas lower levels of the co-inhibitory molecule, PD-L1, were detected in terms of frequency. Notably, the viability, endocytosis, T-cell stimulatory capacity and cytokine

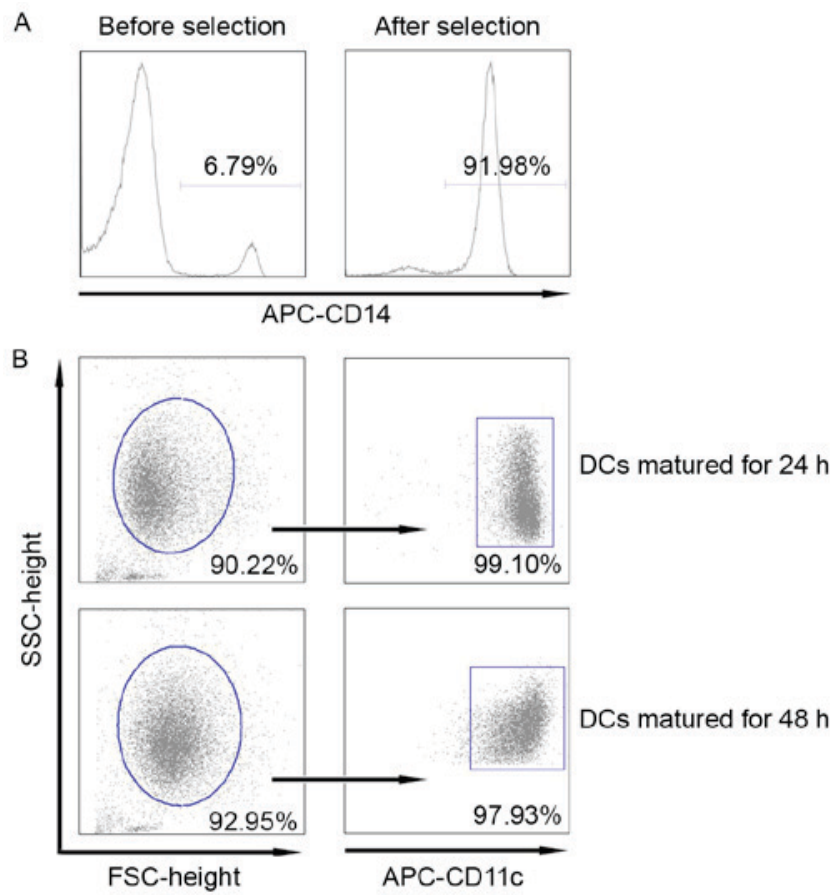

Figure 1. Purity of CD14+ monocytes after selection (A) and purity of DCs matured using a standard cocktail for 24 and $48 \mathrm{~h}$, respectively. (B) Three experiments were performed; one is presented. $\mathrm{CD}$, cluster of differentiation; DCs, dendritic cells; SSC, side scatter; FSC, forward scatter; APC, allophycocyanin.

production were all comparable between DCs matured for 24 and $48 \mathrm{~h}$, respectively.

Pioneering studies indicating the possibility of culturing murine DCs ex vivo from bone marrow precursors initiated DC vaccine development in the 1990s (21). Human applications followed soon thereafter and it was demonstrated that peripheral blood-derived monocytes and CD34+ hematopoietic progenitors are suitable for generating human DCs (22). In previous studies, DCs have been induced from adherent monocytes by washing out non-adherent cells, such as $\mathrm{T}$ and B cells. However, the purity of DCs obtained by this method is $\sim 60 \%$. In the present study, we induced DCs from CD14+ monocytes selected by using human CD14+ microbeads. The purity of DCs obtained from this method exceeds $90 \%$, which is crucial for the improved effectiveness of DC-based immunotherapy (23).

The maturation state of DCs has been considered as a decisive factor in immune responses. Previous clinical studies have demonstrated that improved clinical outcomes were more frequently observed in trials using mature DCs in the therapeutic vaccination of patients with cancer, including prostate cancer, melanoma and glioblastoma (24-26), although moderate clinical benefit was also reported in trials using IL-4 immature DCs (27). Due to their low co-stimulatory and MHC class I and II molecule expression, immature and semi-mature DCs are prone to inducing suboptimal T-cell priming and causing T-cell tolerance. Fully mature DCs (for example, matured with proinflammatory cytokines or TLR agonists) are able to prime CD4+ T and CD8+ T cells $(5,28)$. It is well-known that co-stimulatory molecules, such as CD80 and CD86, have a key role in the induction of effective T cell 


\section{A DCs matured for $24 \mathrm{~h}$ DCs matured for $48 \mathrm{~h}$}

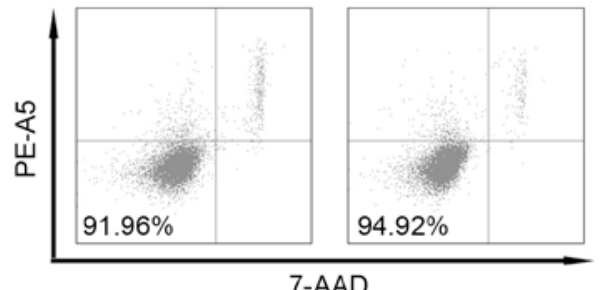

B
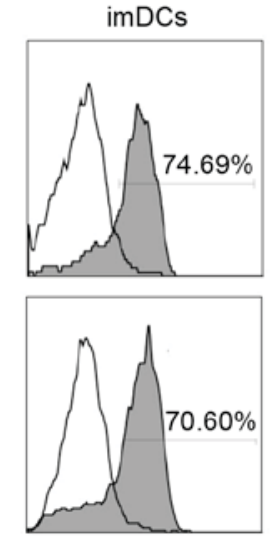

FITC-dextran

Figure 2. Comparison of (A) viability and (B) endocytosis of DCs matured for 24 and $48 \mathrm{~h}$, respectively. Three experiments were performed; one is presented. DCs, dendritic cells; mDC, mature dendritic cells; imDCs, immature dendritic cells.

\section{DCs matured for $24 \mathrm{~h}$} $\square$ DCs matured for $48 \mathrm{~h}$

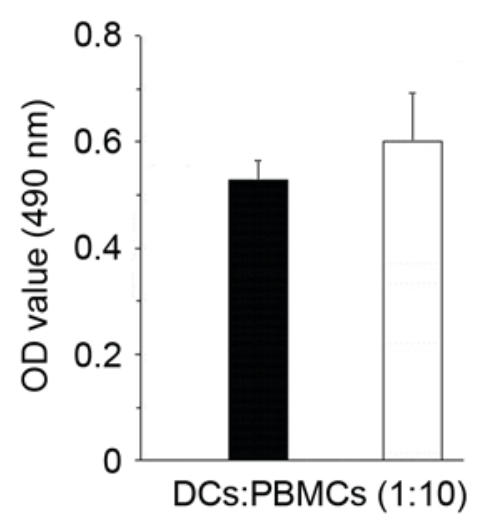

Figure 3. Comparison of T cell stimulatory capacity of DCs matured for 24 or $48 \mathrm{~h}$. Data are presented as the mean + standard deviation. DCs, dendritic cells; OD, optical density.

responses (29). Our data showed that DCs matured for 24 and $48 \mathrm{~h}$, respectively, expressed high levels of CD80 and CD86, which are important for the initiation of a robust immune response. Furthermore, CD40, which also has a critical role in $\mathrm{T}$ cell activation $(30,31)$ expressed even higher levels in DCs matured for $24 \mathrm{~h}$. Notably, PD-L1, which is well-known for its inhibitory role in T cell activation (32-34), expressed relatively lower levels on DCs matured for $24 \mathrm{~h}$ and this may be beneficial for $\mathrm{T}$ cell priming.

It is increasingly recognized that abundant production of IL-12, particularly IL-12p70 during DC maturation has a
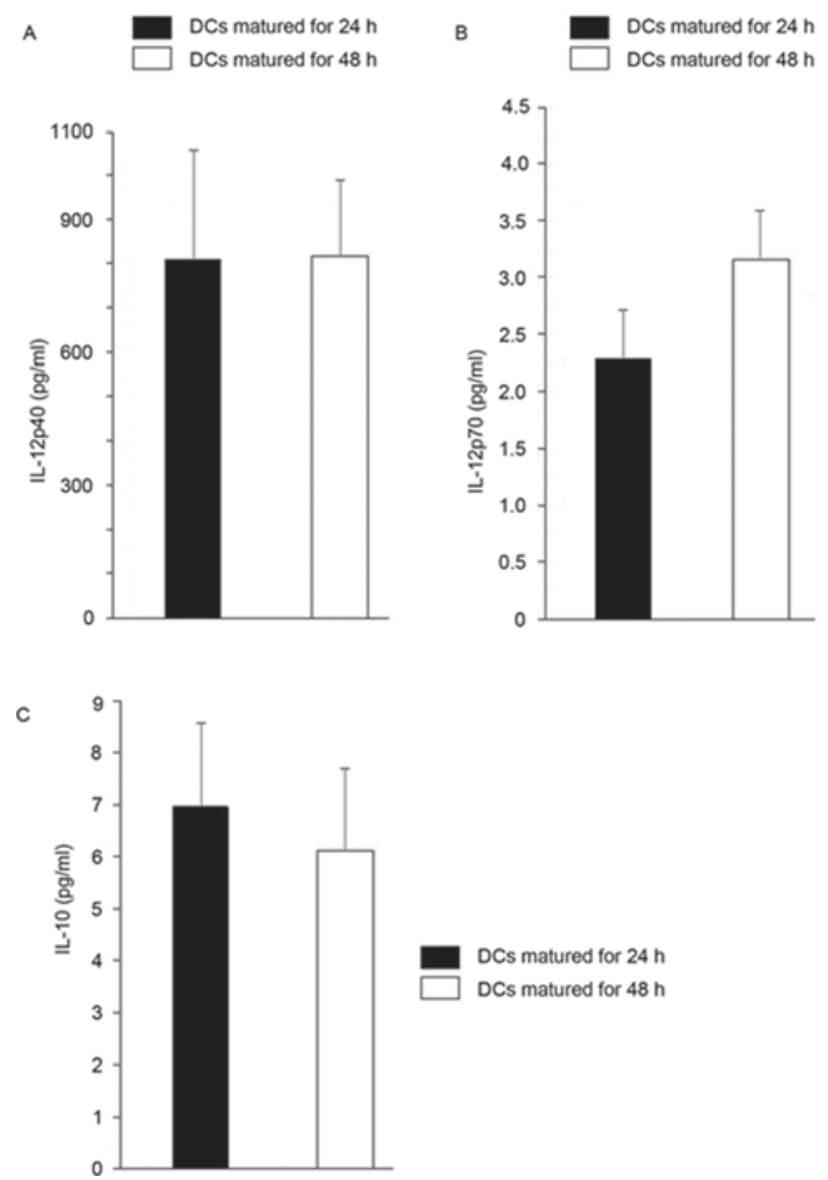

Figure 4. Comparison of the cytokine secretion of DCs matured for 24 or $48 \mathrm{~h}$, respectively. Production of (A) IL-12p40, (B) IL-12p70 and (C) IL-10. Data are presented as the mean + standard deviation. DCs, dendritic cells; IL, interleukin.

crucial role in the differentiation and expansion of Th1 cell and Th1-polarized immunity $(13,35,36)$. In clinical trials of melanoma (37) and glioblastoma (38), favorable outcomes were observed to be related to DC1-derived IL-12p70 production and Th1-polarized immunity. Similar to previous studies $(39,40)$, the present study found that although DCs matured with a different time span secreted higher levels of IL-12p40, and secreted little bioactive IL-12p70. Therefore, studies to further improve the capacity of DCs to produce bioactive IL-12p70 are necessary. IL-10, known as an anti-inflammatory and immunosuppressive cytokine, was first described as a product of Th2 cells that inhibited cytokine synthesis in Th1 cells (41). It is now known that multiple immune cells, including macrophages, dendritic cells (DC), $\mathrm{B}$ cells, and various subsets of CD4+ and CD8+ T cells, are able to produce IL-10 (42). IL-10 inhibits the capacity of antigen-presenting cells, including DCs and macrophages, to present antigens to $\mathrm{T}$ cells in various ways to modulate immune responses (43). Recently, tumor cell-secreted IL-10 has been demonstrated to counteract the immunity of modified DCs in an established tumor model, which indicated that the high level of IL-10 within tumor microenvironment may impair DC vaccine functions (44). In the present study, DCs matured with the standard cocktail for different time spans (24 and $48 \mathrm{~h}$ ) secreted minimal IL-10, which is a positive factor for DCs exerting immune responses. 
High viability is another important factor in DC-based immunotherapy. In fact, DCs will gradually lose their function in a few days after maturation owing to apoptosis (17). In our present study, DCs matured for 24 and 48 h, respectively, exhibited high viability. The high viability may be due to the addition of PGE2 to the cocktail as previous studies have shown that PGE2 promotes apoptotic resistance and survival of DCs $(45,46)$.

In conclusion, our preliminary results indicated that 24-h stimulation is sufficient for DC maturation when using IL-1 $\beta$, IL-6, TNF- $\alpha$ and PGE2. Reducing the time to mature DCs in vitro from 48 to $28 \mathrm{~h}$ may be beneficial for the optimal preparation of tumor-pulsed DC therapeutic vaccine and improve its in vivo effectiveness.

\section{Acknowledgements}

The present study was supported by grants from the National Natural Science Foundation of China (grant no. 81400621) and the Mega-projects of Science Research (grant no. 008ZX10002-008).

\section{References}

1. Banchereau J and Steinman RM: Dendritic cells and the control of immunity. Nature 392: 245-252, 1998.

2. Kushwah R and Hu J: Complexity of dendritic cell subsets and their function in the host immune system. Immunology 133 : 409-419, 2011

3. Schraml BU and Reis e Sousa C: Defining dendritic cells. Curr Opin Immunol 32: 13-20, 2015.

4. Guermonprez P, Valladeau J, Zitvogel L, Théry C and Amigorena S: Antigen presentation and $\mathrm{T}$ cell stimulation by dendritic cells. Annu Rev Immunol 20: 621-667, 2002.

5. Lutz MB and Schuler G: Immature, semi-mature and fully mature dendritic cells: Which signals induce tolerance or immunity? Trends Immunol 23: 445-449, 2002.

6. Romani N, Gruner S, Brang D, Kampgen E, Lenz A, Trockenbacher B, Konwalinka G, Fritsch PO, Steinman RM and Schuler G: Proliferating dendritic cell progenitors in human blood. J Exp Med 180: 83-93, 1994.

7. Sallusto F and Lanzavecchia A: Efficient presentation of soluble antigen by cultured human dendritic cells is maintained by granulocyte/macrophage colony-stimulating factor plus interleukin 4 and downregulated by tumor necrosis factor alpha. J Exp Med 179: 1109-1118, 1994.

8. Jonuleit H, Kühn U, Müller G, Steinbrink K, Paragnik L, Schmitt E, Knop J and Enk AH: Pro-inflammatory cytokines and prostaglandins induce maturation of potent immunostimulatory dendritic cells under fetal calf serum-free conditions. Eur J Immunol 27: 3135-3142, 1997.

9. Zheng Z, Takahashi M, Narita M, Toba K, Liu A, Furukawa T, Koike T and Aizawa Y: Generation of dendritic cells from adherent cells of cord blood by culture with granulocyte-macrophage colony-stimulating factor, interleukin- 4 , and tumor necrosis factor-alpha. J Hematother Stem Cell Res 9: 453-464, 2000.

10. Boullart AC, Aarntzen EH, Verdijk P, Jacobs JF, Schuurhuis DH, Benitez-Ribas D, Schreibelt G, van de Rakt MW, Scharenborg NM, de Boer A, et al: Maturation of monocyte-derived dendritic cells with Toll-like receptor 3 and $7 / 8$ ligands combined with prostaglandin E2 results in high interleukin-12 production and cell migration. Cancer Immunol Immunother 57: 1589-1597, 2008.

11. Anguille S, Smits EL, Cools N, Goossens H, Berneman ZN and Van Tendeloo VF: Short-term cultured, interleukin-15 differentiated dendritic cells have potent immunostimulatory properties. J Transl Med 7: 109, 2009.

12. Schuler-Thurner B, Schultz ES, Berger TG, Weinlich G, Ebner S, Woerl P, Bender A, Feuerstein B, Fritsch PO, Romani N and Schuler G: Rapid induction of tumor-specific type $1 \mathrm{~T}$ helper cells in metastatic melanoma patients by vaccination with mature, cryopreserved, peptide-loaded monocyte-derived dendritic cells. J Exp Med 195: 1279-1288, 2002.
13. Xu S, Koski GK, Faries M, Bedrosian I, Mick R, Maeurer M, Cheever MA, Cohen PA and Czerniecki BJ: Rapid high efficiency sensitization of CD8+ T cells to tumor antigens by dendritic cells leads to enhanced functional avidity and direct tumor recognition through an IL-12-dependent mechanism. J Immunol 171: 2251-2261, 2003.

14. Ellebaek E, Engell-Noerregaard L, Iversen TZ, Froesig TM, Munir S, Hadrup SR, Andersen MH and Svane IM: Metastatic melanoma patients treated with dendritic cell vaccination, Interleukin-2 and metronomic cyclophosphamide: Results from a phase II trial. Cancer Immunol Immunother 61: 1791-1804, 2012.

15. Vik-Mo EO, Nyakas M, Mikkelsen BV, Moe MC, Due-Tønnesen P, Suso EM, Sæbøe-Larssen S, Sandberg C, Brinchmann JE, Helseth E, et al: Therapeutic vaccination against autologous cancer stem cells with mRNA-transfected dendritic cells in patients with glioblastoma. Cancer Immunol Immunother 62: 1499-1509, 2013.

16. Berntsen A, Trepiakas R, Wenandy L, Geertsen PF, thor Straten P, Andersen MH, Pedersen AE, Claesson MH, Lorentzen T, Johansen JS and Svane IM: Therapeutic dendritic cell vaccination of patients with metastatic renal cell carcinoma: A clinical phase 1/2 trial. J Immunother 31: 771-780, 2008.

17. Lanzavecchia A and Sallusto F: Regulation of T cell immunity by dendritic cells. Cell 106: 263-266, 2001.

18. Mellman I: Dendritic cells: Master regulators of the immune response. Cancer Immunol Res 1: 145-149, 2013.

19. Leverkus M, Walczak H, McLellan A, Fries HW, Terbeck G, Bröcker EB and Kämpgen E: Maturation of dendritic cells leads to up-regulation of cellular FLICE-inhibitory protein and concomitant down-regulation of death ligand-mediated apoptosis. Blood 96: 2628-2631, 2000.

20. Krause P, Singer E, Darley PI, Klebensberger J, Groettrup M and Legler DF: Prostaglandin E2 is a key factor for monocyte-derived dendritic cell maturation: Enhanced T cell stimulatory capacity despite IDO. J Leukoc Biol 82: 1106-1114, 2007.

21. Young JW and Steinman RM: Accessory cell requirements for the mixed-leukocyte reaction and polyclonal mitogens, as studied with a new technique for enriching blood dendritic cells Cell Immunol 111: 167-182, 1988.

22. Markowicz S and Engleman EG: Granulocyte-macrophage colony-stimulating factor promotes differentiation and survival of human peripheral blood dendritic cells in vitro. J Clin Invest 85: 955-961, 1990.

23. Wang W, Li J, Wu K, Azhati B and Rexiati M: Culture and identification of mouse bone marrow-derived dendritic cells and their capability to induce T lymphocyte proliferation. Med Sci Monit 22: 244-250, 2016

24. Draube A, Klein-González N, Mattheus S, Brillant C, Hellmich M, Engert A and von Bergwelt-Baildon M: Dendritic cell based tumor vaccination in prostate and renal cell cancer: A systematic review and meta-analysis. PLoS One 6: e18801, 2011.

25. de Vries IJ, Lesterhuis WJ, Scharenborg NM, Engelen LP, Ruiter DJ, Gerritsen MJ, Croockewit S, Britten CM, Torensma R, Adema GJ, et al: Maturation of dendritic cells is a prerequisite for inducing immune responses in advanced melanoma patients. Clin Cancer Res 9: 5091-5100, 2003.

26. Yamanaka R, Homma J, Yajima N, Tsuchiya N, Sano M, Kobayashi T, Yoshida S, Abe T, Narita M, Takahashi M and Tanaka R: Clinical evaluation of dendritic cell vaccination for patients with recurrent glioma: Results of a clinical phase I/II trial. Clin Cancer Res 11: 4160-4167, 2005.

27. Anguille S, Smits EL, Lion E, van Tendeloo VF and Berneman ZN: Clinical use of dendritic cells for cancer therapy. Lancet Oncol 15: e257-e267, 2014.

28. Cintolo JA, Datta J, Mathew SJ and Czerniecki BJ: Dendritic cell-based vaccines: Barriers and opportunities. Future Oncol 8: 1273-1299, 2012

29. Greenwald RJ, Freeman GJ and Sharpe AH: The B7 family revisited. Annu Rev Immunol 23: 515-548, 2005.

30. Taraban VY, Rowley TF and Al-Shamkhani A: Cutting edge: A critical role for CD70 in CD8 T cell priming by CD40-licensed APCs. J Immunol 173: 6542-6546, 2004.

31. Ma DY and Clark EA: The role of CD40 and CD154/CD40L in dendritic cells. Semin Immunol 21: 265-272, 2009.

32. Freeman GJ, Long AJ, Iwai Y, Bourque K, Chernova T, Nishimura H, Fitz LJ, Malenkovich N, Okazaki T, Byrne MC, et al: Engagement of the PD-1 immunoinhibitory receptor by a novel $\mathrm{B} 7$ family member leads to negative regulation of lymphocyte activation. J Exp Med 192: 1027-1034, 2000. 
33. Carter L, Fouser LA, Jussif J, Fitz L, Deng B, Wood CR, Collins M, Honjo T, Freeman GJ and Carreno BM: PD-1:PD-L inhibitory pathway affects both CD4(+) and CD8(+) T cells and is overcome by IL-2. Eur J Immunol 32: 634-643, 2002.

34. Selenko-Gebauer N, Majdic O, Szekeres A, Höfler G, Guthann E, Korthäuer U, Zlabinger G, Steinberger P, Pickl WF, Stockinger $\mathrm{H}$, et al: B7-H1 (programmed death-1 ligand) on dendritic cells is involved in the induction and maintenance of T cell anergy. J Immunol 170: 3637-3644, 2003.

35. Trinchieri G: Interleukin-12 and the regulation of innate resistance and adaptive immunity. Nat Rev Immunol 3: 133-146, 2003

36. Strioga MM, Felzmann T, Powell DJ Jr, Ostapenko V, Dobrovolskiene NT, Matuskova M, Michalek J and Schijns VE: Therapeutic dendritic cell-based cancer vaccines: The state of the art. Crit Rev Immunol 33: 489-547, 2013.

37. Carreno BM, Becker-Hapak M, Huang A, Chan M, Alyasiry A, Lie WR, Aft RL, Cornelius LA, Trinkaus KM and Linette GP: IL-12p70-producing patient DC vaccine elicits Tc1-polarized immunity. J Clin Invest 123: 3383-3394, 2013.

38. Okada H, Kalinski P, Ueda R, Hoji A, Kohanbash G, Donegan TE, Mintz AH, Engh JA, Bartlett DL, Brown CK, et al: Induction of CD8+ T-cell responses against novel glioma-associated antigen peptides and clinical activity by vaccinations with \{alpha\}-type 1 polarized dendritic cells and polyinosinic-polycytidylic acid stabilized by lysine and carboxymethylcellulose in patients with recurrent malignant glioma. J Clin Oncol 29: 330-336, 2011.

39. Lee AW, Truong T, Bickham K, Fonteneau JF, Larsson M, Da Silva I, Somersan S, Thomas EK and Bhardwaj N: A clinical grade cocktail of cytokines and PGE2 results in uniform maturation of human monocyte-derived dendritic cells: Implications for immunotherapy. Vaccine 20 (Suppl 4): A8-A22, 2002.
40. Trepiakas R, Pedersen AE, Met O, Hansen MH, Berntsen A and Svane IM: Comparison of alpha-Type-1 polarizing and standard dendritic cell cytokine cocktail for maturation of therapeutic monocyte-derived dendritic cell preparations from cancer patients. Vaccine 26: 2824-2832, 2008.

41. Fiorentino DF, Bond MW and Mosmann TR: Two types of mouse T helper cell. IV. Th2 clones secrete a factor that inhibits cytokine production by Th1 clones. J Exp Med 170: 2081-2095, 1989.

42. Couper KN, Blount DG and Riley EM: IL-10: The master regulator of immunity to infection. J Immunol 180: 5771-5777, 2008.

43. Mittal SK and Roche PA: Suppression of antigen presentation by IL-10. Curr Opin Immunol 34: 22-27, 2015.

44. Song S, Wang Y, Wang J, Lian W, Liu S, Zhang Z, Liu F and Wei L: Tumour-derived IL-10 within tumour microenvironment represses the antitumour immunity of Socs1-silenced and sustained antigen expressing DCs. Eur J Cancer 48: 2252-2259, 2012.

45. Vassiliou E, Sharma V, Jing H, Sheibanie F and Ganea D Prostaglandin E2 promotes the survival of bone marrow-derived dendritic cells. J Immunol 173: 6955-6964, 2004.

46. Baratelli F, Krysan K, Heuzé-Vourc'h N, Zhu L, Escuadro B, Sharma S, Reckamp K, Dohadwala M and Dubinett SM: PGE2 confers survivin-dependent apoptosis resistance in human monocyte-derived dendritic cells. J Leukoc Biol 78: 555-564, 2005. 